Volume 9, No.1.3, 2020

International Journal of Advanced Trends in Computer Science and Engineering Available Online at http://www.warse.org/IJATCSE/static/pdf/file/ijatcse3291.32020.pdf

https://doi.org/10.30534/ijatcse/2020/3291.32020

\title{
Enhanced Decision Support System for Automated Fish Feeder and Water Quality Detection with SMS Notification
}

\author{
Audelon R. Benito \\ Isabela State University - Roxas, Isabela, Philippines, audelon.r.benito@isu.edu.ph
}

\begin{abstract}
This study aimed to address the identified problems and issues encountered within the existing process of fish farming through the Enhanced Decision Support System for Automated Fish Feeder and Water Quality Detection with SMS Notification. The extent of compliance of the developed system to International Standard Organization 25010 Software Quality Standard was evaluated using survey questionnaires thru 5 points Likert Scale between Information Technology experts and Users. Research and Development (R\&D), V-model and Data Gathering Procedures have been applied. Findings showed that the participants gave a Very Great Extent of compliance with ISO 25010. The developed system has the ability to feed the fishes based on the time set by the user. Water Quality parameter sensors have been used to detects water quality in real-time. The developed system has met the intended tasks to do like Feeding and Water Quality Monitoring. This concludes that the existing system can be enhanced by means of Technological Innovations. Deployment of the developed system will offer a convenient and efficient way of fish farming.
\end{abstract}

Key words : Aquaculture, Automated Feeder, ISO 25010, Water Quality Parameters.

\section{INTRODUCTION}

Fish farming is one of the basic economics in the Philippines. However the current situation in fish management has negative impact in the environment. In [1] the fish farming can contribute to pollution due to increase of fish waste and left over feeds, these may result to negative impact to their environment and may result to water contamination that may led to fish kill. Many of the Filipinos are engaged in fish farming both natural and artificial method. In 2018, the total volume of fisheries production was estimated at 4.35 million metric tons, which was 0.92 percent higher than its previous year's level of 4.31 million metric tons [2]. Like other creatures that need a place to stay, fish are raised in fish cages, fish ponds, and fish tanks.
Fish raisers duties are feeding the fishes regularly, in real-time, proper amount of feeds to be disposed and checking of water quality parameters are significant. When the researcher conducted an interview and observation with the fish raisers, they stated that the problems they encountered are feeding and managing the water qualities. During feeding the time they cannot attain the proper rate and time because of their farm location or they need to go in other farm location other scenarios are during emergencies, typhoons, and the rainy season, because of this interference, the fish raisers could not immediately reach their farm. Some fish raisers hired assistants to do the said activities hence there is still negligence for the reason that they just repeat the mismanagement practices such us in-proper feeding and hiring of farm assistants will increase their production costs that may affect their income. The fish raisers stated also that on the side of the water quality parameters they do not pay much attention. Engaging this kind of setup entails a lot of duties and responsibilities. That is why fish raisers need more patience and determination to do this job. One's duty is neglected such as mismanagement and mishandling of fish needs when owners forget to feed their fishes. Other scenarios are overfeeding, insufficient feeding, feeding them not on time and un-monitored water quality parameters such as temperature, dissolved oxygen, $\mathrm{pH}$ level, water level, and ammonia affect the life of fishes.

The study of [3] proves that too much feed given during feeding time may result in having left over feeds which eventually produced an environmental bad effect. The effect is very dangerous for the reason that, it will result in water contamination that will influence the water qualities while article [4] stated that the feeding problem arises especially in large fish ponds. Water quality monitoring and controlling must be practiced regularly to achieve great production [5] while [6] stated that to increase the production of healthy fish and to make it more profitable, a better water quality is needed. These tasks are extremely demanding in the side of fish raisers. 
Audelon R. Benito, International Journal of Advanced Trends in Computer Science and Engineering, 9(1.3), 2020, 215 - 221

Fish farming automation like automated fish feeder is needed to solve the challenges in fish farming. It is a system that capable of feeding the fishes in real-time base on the time set by the user. It also monitors the feedstock in the feed storage, notifies the user regarding feeding time, feeds the remaining level, and detects water quality parameters. The article [7] emphasized that the use of controlled feeding mechanism ensures the consistency of the time and feeding plan will eliminate the problems of manual practices in feeding and lessen the labor cost, while [8] mentioned that using a smart system for farming can solve the issues of food security and sustainability in reasonable production cost.

\section{METHODOLOGY}

The research and development method was selected by the researcher as the suitable methodology for this study. Research and development are combination of both basic and applied research. The goal of this method was to develop new tools, useful technique and solution to problems in order to improve the existing system based on a systematic method. Moreover, the researcher made use of R \& D to study available information in order to be used as a concept and Prototype in developing the system.

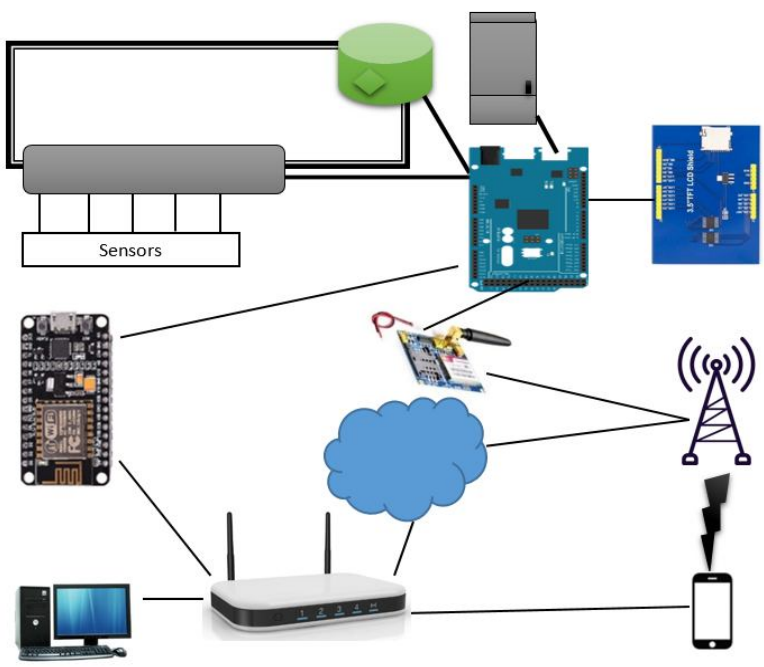

Figure 1: The System Concepts and Architecture of the developed system

The figure 1 shows the system concept of the study. The output of the study is equipped with Internet of Things (IoT) to manage the system and collected data through Internet. Internet of Things (IoT) is categorized as rampant technology that can handle huge amount of data because of the infrastructure support for better process and services [9]. In addition, [10] stated that using the Internet of things (IoT) is the new revolution of the internet, even at a far distance it can monitor and give proper data for a diagnostic report because of the real-time result. The researcher used Arduino Microcontroller in developing the system. The sensors are interconnected to Arduino Mega 2560. It monitors and checks Water Temperature, $\mathrm{pH}$ Level, Dissolved Oxygen, Water Level, Turbidity and Ammonia of water. The Automatic fish feeders are connected to Arduino to feed the aqua species during feeding time set by the user. The management can monitor and view the data using 3.5 LCD. They can also receive notifications and alerts during feeding time, feeds storage level, and any irregularities on water quality parameters through GSM module connected on Arduino. The gathered data of the water parameters will be transmitted be by the NodeMCU through WiFi connection connected to the computer and store it in the database. The stored data can be viewed by using Web browser by local Area network and Internet.

\subsection{Locale of the Study}

This study was conducted at the Provincial Institute of Fisheries (PIF), Department of Isabela State University - Roxas Campus, Roxas, Isabela to modernize their traditional way of Fish Feeding and Water Quality Monitoring through Innovation. The Provincial Institute of Fisheries (PIF) Department is located at Mid Site, one of the three sites of Isabela State University-Roxas Campus. PIF Department has (25) Fish Ponds, (16) Fish Tanks and (25) aquariums.

\subsection{Participants of the Study}

The participants of the study were the (5) Faculty members, (1) Farm Worker/ Guard and (14) students who were selected for the reason that they are involved in monitoring the fishes. The developed system was evaluated by (10) Information Technology experts as participants to determine its compliance to the ISO 25010 software quality standards. The participants of this study were conveniently selected.

Table 1: Distribution of the Participants of the Study

\begin{tabular}{|l|c|c|}
\hline \multicolumn{1}{|c|}{ Participants } & $\begin{array}{c}\text { Number of } \\
\text { Participants }\end{array}$ & Percentage \\
\hline Faculty Members & 5 & $17 \%$ \\
\hline Farm Aid/Guard & 1 & $3 \%$ \\
\hline Students & 14 & $47 \%$ \\
\hline IT Experts & 10 & $33 \%$ \\
\hline Total & $\mathbf{3 0}$ & $\mathbf{1 0 0 \%}$ \\
\hline
\end{tabular}


Audelon R. Benito, International Journal of Advanced Trends in Computer Science and Engineering, 9(1.3), 2020, 215 - 221

\subsection{Instrumentation}

This phase shows the instrumentation used by the researcher for data gathering process to get qualitative data. The primary aim of the instrumentation is to determine the process used by the Institute in their existing system and to list down the problems and issues the participants usually encounter.

\subsection{Interview Guide}

The researcher made an interview guide questionnaire. This instrument was used to gather information and get the residents' feedback on problems encountered in the existing practices of the department on how they feed and check the water quality parameters. The researcher interviewed the participants in gathering information about the overall process using the interview guide questionnaire. The information gathered from the interview were used as basis for the development of the system. Written assessments were applied in this tool and answers regarding the problems encountered in the existing system and what proposed system can be developed to address the identified problem and issues in the existing system.

\subsection{Observation}

This instrumentation was used to determine the strengths and weaknesses of the existing system. The researcher observed the process done in aquaculture to familiarize with the current procedure on how they feed and check the water quality parameters based on the existing system. This was also used in system implementation wherein the researcher observed the performance of the developed system for some faults that were encountered.

\subsection{Data Gathering Procedure}

The first stage taken before the conduct of the research was to request permission from the Director of the Provincial Institute of Fisheries. The next one was to ask the Department Chairperson to officially conduct the research.

Informal interviews and observations were conducted in order to gather more data relative to the study. The researcher interviewed the Director of Fisheries, Faculty members, Farm Aid and selected students regarding the existing process on fish feeding and water quality monitoring. During the interview, the researcher distributed Interview Guide Questionnaires to be answered by the participants.
The researcher collected the Interview Guide Questionnaires and used as basis in developing the system.The researcher conducted data collection using observation, the researcher properly documented the process executed and used as basis the processes in fish feeding and checking of water quality parameters. .To conduct a survey, the researcher used ISO 25010 Software Quality Standard survey questionnaire to assess the developed systems of extent of compliance to ISO 25010 as assessed by the participants. The data were recorded by the researcher then analyzed, interpreted and applied the statistical treatment through the guidance of the researcher's adviser and data consultant.

Informed consent was used in data gathering of this study. Informed consent requires detailed and truthful statement between the researcher and the participants of the study. Informed consent forms are divided into two parts these are Information sheet used to gather basic information of the participants and Certificate of Consent wherein the consent form is used to inform the participants that their consent is voluntarily to participate in research.

\subsection{Data Analysis}

The data gathered were tabulated and tallied for the purpose of interpretation and analysis. The data were analyzed using Two-Independent Samples of T-Test. Mean was used to analyze the average rating of the IT experts and users with regards to ISO 25010 compliance and system extend of compliance in ISO 25010 of the participants evaluation was interpreted using the scales below.

Table 2: Extent of compliance of the developed system to ISO 25010 Software Quality Standards

\begin{tabular}{|l|l|l|}
\hline Range & Weighted Mean & \multicolumn{1}{c|}{ Description } \\
\hline 5 & $4.20-5.00$ & Very Great Extent \\
\hline 4 & $3.40-4.19$ & Great Extent \\
\hline 3 & $2.60-3.39$ & Moderate Extent \\
\hline 2 & $1.80-2.59$ & Low Extent \\
\hline 1 & $1.00-1.79$ & Very Low Extent \\
\hline
\end{tabular}

Table 3: Significant difference in the extent of compliance of the developed system to ISO 25010 Software Quality standards as assessed by the IT Experts and Users

\begin{tabular}{|l|l|}
\hline \multicolumn{1}{|c|}{ P Value } & \multicolumn{1}{c|}{ Weighted Mean } \\
\hline $\begin{array}{l}\text { Greater than Equal to } \\
(0.001)\end{array}$ & Highly Significant \\
\hline Less than to $(0.05)$ & Significant \\
\hline Greater than to $(0.05)$ & Not Significant \\
\hline
\end{tabular}


Audelon R. Benito, International Journal of Advanced Trends in Computer Science and Engineering, 9(1.3), 2020, 215 - 221

\section{RESULTS AND DISCUSSION}

\subsection{The problems and issues encountered by users in the existing system:}

1. During feeding time, one of the major problems is un-eaten or unconsumed feeds that were thrown on the water, for the reason that it does not meet the right feeding rate or amount.

2. Feeding time is also a problem for the reasons that only few people were assigned to do the activities because others must do also their activities.

3. Farm Aid could not immediately reach the fish farm location in time because of interference such as distance, typhoons, emergencies and rainy seasons.

4. There are no existing confirmations that they feed the fishes especially on weekends or holidays.

\subsection{Existing Practices on Water Quality Monitoring}

Checking of Water Qualities are important elements on the animals living in water[11]. It is essential to check water quality parameters because it affects the survival and growth of aquaculture animals.

Based on the instrumentation used, water qualities were monitored only during laboratory time or not in real time in checking if the water is contaminated or not in normal conditions. The farmworker check only when he has a time to make it.

\subsection{Issues}

Based on the instrumentation used, the faculty members and farm worker have many activities to do aside from taking care of the fishes. Managing of (25) Fish Ponds, (16) Fish Tanks and (25) Aquariums are big task to do.

It is hard for them to do simultaneously all the activities like fish feeding 2 to 3 times a day and monitoring of water quality parameters in real time. Another issue is the process of how they drop the feeds. The researcher observed that the people assigned on feeding threw only in one direction that may cause injury to the fishes for the reason that the fish will take advantage of the other fishes to reach the food that may injured them or the other fish and may result to a fish kill.

\subsection{The developed system addresses the identified problems and issues in the existing system.}

In general, the developed system determined first the water quality such as Turbidity, Water Level, $\mathrm{pH}$ level, Dissolve Oxygen, Ammonia, and Temperature before disposing of the feeds. The system is equipped with a decision support system to initiate first aid action on the water quality such as low water level, low oxygen level, high turbidity, high temperature, and ammonia.

The developed system automatically disposes of feeds based on the feeding hour in real time. Feeding Proper Rate will lessen the left-over feeds and water contamination is avoided. The farmworker and managements will receive SMS notification that the fishes are fed in real time, frequency and the current Feeds storage level of the feeder machine. The automated feeder has a propeller that is used to throw feed in the fish pond and tanks. Fish pond automated feeder can throw feeds up to (7) meters away, the machine can throw feeds in multiple directions up to (4) meters widespread to avoid fish injury. On the side of water quality, the system monitors the qualities if there's something unusual value detected, the system will alarm the siren and send SMS notifications to the farmworker. The developed system uses a renewable source of energy to ensure its low cost in operation, lessen human effort and more profitable. Utilizing renewable energy sources like solar energy are efficient and minimize the cost of labor [12].

On the side of water quality parameters, the developed system monitors in real time the parameters and gives Siren warning and SMS notifications to the Farmworker/ Farm Owner if the sensors detect something unusual. [13] Using water quality sensor for fish farming can optimize the use of resources and improve its sustainability and profitability. The researcher developed the system using Arduino Mega and water parameter sensors. These water quality sensors will check the parameters and give notification if something unusual value is detected. In order to meet the actual production of fish farming, water the quality monitoring system is needed for aquaculture ponds and tanks through the use of microcontroller and sensors that can obtain water quality parameters in real-time [14]. Data gathered from the water quality parameter sensors can be viewed through a web browser using the Internet. 
Audelon R. Benito, International Journal of Advanced Trends in Computer Science and Engineering, 9(1.3), 2020, 215 - 221

3.5 Significant difference between the assessment of the IT Experts and Users on the extent of compliance of the developed system to ISO 25010 Software Quality Standards as assessed by the IT Experts and Users.

Table 4: Significant assessment of IT Experts and Users on the developed system on the extent of compliance to ISO 25010 Software Quality Standards

\begin{tabular}{|c|c|c|c|c|c|c|}
\hline ISO Standards & $\begin{array}{l}\text { Type of } \\
\text { Participants }\end{array}$ & $\begin{array}{l}\text { Overall } \\
\text { Category } \\
\text { Weighted Mean }\end{array}$ & $\begin{array}{l}\text { Descriptive } \\
\text { Rating }\end{array}$ & $\begin{array}{l}\mathrm{F} \\
\text { Value }\end{array}$ & \begin{tabular}{|l|}
$\mathrm{P}$ \\
Value
\end{tabular} & Remarks \\
\hline \multirow{2}{*}{$\begin{array}{l}\text { Functional } \\
\text { Sustainability }\end{array}$} & IT Experts & 4.50 & Very Great Extent & \multirow{2}{*}{0.263} & \multirow{2}{*}{0.612} & \multirow{2}{*}{$\begin{array}{l}\text { Not } \\
\text { Significant }\end{array}$} \\
\hline & Users & 4.47 & Very Great Extent & & & \\
\hline \multirow{2}{*}{$\begin{array}{l}\text { Performance } \\
\text { Efficiency }\end{array}$} & IT Experts & 4.43 & Very Great Extent & \multirow{2}{*}{1.724} & \multirow{2}{*}{0.200} & \multirow{2}{*}{$\begin{array}{l}\text { Not } \\
\text { Significant }\end{array}$} \\
\hline & Users & 4.28 & Very Great Extent & & & \\
\hline \multirow[b]{2}{*}{ Compatibility } & IT Experts & 4.50 & Very Great Extent & \multirow[b]{2}{*}{0.356} & \multirow[b]{2}{*}{0.556} & \multirow{2}{*}{$\begin{array}{l}\text { Not } \\
\text { Significant }\end{array}$} \\
\hline & Users & 4.40 & Very Great Extent & & & \\
\hline \multirow{2}{*}{ Usability } & IT Experts & 4.47 & Very Great Extent & \multirow{2}{*}{0.50} & \multirow{2}{*}{0.825} & \multirow{2}{*}{$\begin{array}{l}\text { Not } \\
\text { Significant }\end{array}$} \\
\hline & Users & 4.40 & Very Great Extent & & & \\
\hline \multirow{2}{*}{ Reliability } & IT Experts & 4.30 & Very Great Extent & \multirow{2}{*}{0.283} & \multirow{2}{*}{0.599} & \multirow{2}{*}{$\begin{array}{l}\text { Not } \\
\text { Significant }\end{array}$} \\
\hline & Users & 4.32 & Very Great Extent & & & \\
\hline \multirow[b]{2}{*}{ Security } & IT Experts & 4.30 & Very Great Extent & \multirow[b]{2}{*}{4.483} & \multirow[b]{2}{*}{0.043} & \multirow[b]{2}{*}{ Significant } \\
\hline & Users & 4.27 & Very Great Extent & & & \\
\hline \multirow[b]{2}{*}{ Maintainability } & IT Experts & 4.30 & Very Great Extent & \multirow[b]{2}{*}{1.831} & \multirow[b]{2}{*}{0.187} & \multirow{2}{*}{$\begin{array}{l}\text { Not } \\
\text { Significant }\end{array}$} \\
\hline & Users & 4.28 & Very Great Extent & & & \\
\hline \multirow{2}{*}{ Portability } & IT Experts & 4.37 & Very Great Extent & \multirow{2}{*}{1.822} & \multirow{2}{*}{0.188} & \multirow{2}{*}{$\begin{array}{l}\text { Not } \\
\text { Significant }\end{array}$} \\
\hline & Users & 4.50 & Very Great Extent & & & \\
\hline
\end{tabular}

Tables shows that both IT Experts and Users agreed that the developed system has a very great extent of compliance to ISO 25010 in terms of functional sustainability, performance efficiency, compatibility, usability, reliability, security, maintainability, and portability. It can be inferred that the developed application is highly approved by the participants that the developed application satisfies the stated and implied needs of users in automated feeder and water quality detection. The evaluation also indicates the developed System can solve the problems on the existing system. The IT Experts and Users have the same assessment as to the compliance of the developed system with respect to Functional Sustainability, Performance Efficacy, Compatibility, Usability, Reliability, Maintainability, and Portability. However the assessment of the IT Experts and Users differ in terms of security the assessment of the IT experts is significantly higher than that of the Users. The result confirms the study of [15] used automated fish feeding and water quality monitoring is convenient because it is effective, more efficient and easier than manual process. In addition, the result shows that ISO/IEC 25010: 2011 provide the leading models for assessing software product. Furthermore ISO/IEC 25010: 2011 is an important contribution towards establishing the delivery performance of software processes and proposed improvements [16].

\subsection{The enhancement can be done to improve the developed system}

To improve the system and lessen the human effort, the developed system must use two-way communication for the reason that the current procedure is for notification only. Two-way communication must be added in the developed system in the sense that the user can operate the developed system using mobile devices and internet. Using mobile application provide broader access to emergency response because of its accessibility [17].

The system must have anti-bacteria water treatment to prevent fish diseases. Also, the developed system must equip with a data mining method, a technique that has possible activities for solving conflicts in aquaculture feeding and water quality parameters processes that can be used to predict the future. [18] Predictive analysis through data mining is used to predict the future to prevent diseases at the early stage while [19] mentioned that data mining is used for predicting and analyzing the performance. Artificial intelligence can be added to help the process for more accuracy, it could lessen the processes performed by the fish farmer using artificial neural network [20].

Sensors gathered data are essential to monitor. Adding fuzzy logic will enhance the develop system response time, making decision capability and very robust, supports for multiple input and output [21].

\section{CONCLUSION}

Based on the findings of the study, the following were concluded:

1. The developed system has met the intended tasks to do such as feeding in real time, proper feeding rate, frequency and water quality monitoring.

2. The existing system can be enhanced by means of technological innovations.

3. The developed system has met the ISO 25010 Software Quality standards characteristics.

4. It is also proven that the developed system has the ability to feed the fishes based on time set by the user.

5. The system distributed feeds in scattered way to avoid fish injury. 
Audelon R. Benito, International Journal of Advanced Trends in Computer Science and Engineering, 9(1.3), 2020, 215 - 221

6. It also monitors water qualities to detect any threats before it gets worse and spread.

7. The sensors used for this purpose are Ammonia, pH probe, Dissolve Oxygen, Water Level, Turbidity and Temperature.

8. The Enhanced Decision Support System for Automated Feeding and Water Quality Detection with SMS Notification is a modern way of fish feeding and water quality monitoring which can be trusted for Smart Fish farming.

\section{RECOMMENDATIONS}

The researcher highly recommends the implementation of this developed system, for the Fisheries Department of Isabela State University- Roxas Campus.

The researcher hereby recommends also the following:

\subsection{For the Farmworker}

1. Replacement of the batteries with bigger one and should be done every 2 years

2. Replacement of the control box with solid box to ensure the durability of the controller.

3. Checking the area of the developed system to maintain its good condition.

\subsection{For the Faculty}

1. Using of a traditional test kit or other testing devices to check the sensors to ensure if they are still producing reliable data or need to calibrate.

2. Properly use of the developed system.

\subsection{For the Administration}

1. The Administration must fully support the implementation and further development of the developed system.

\section{REFERENCES}

1. Wells, K. (updated 2019). The Problems with Fish Farming. wellnessmama.com/105599/fish-farming

2. Philippine Statistics Authority January December 2018 Fisheries situation Report www.psa.gov.ph

3. Adegboye, Mutiu \& Aibinu, A. \& Orire, J \& Folorunso, A \& Aliyu, T. (2017). A Vibration Processing Analysis Approach to the Development of Fish Feeding Regime System. 8. 141-148.

4. Ritu Prem, V.K.Tewari, (2019), Development of human-powered fish feeding machine for freshwater aquaculture farms of developing countries.doi.org/10.1016/j.aquaeng.2019.102028

5. Lugo, A. et al. (2020). Monitoring of water quality in a shrimp farm using a FANET. Internet of Things (2020), doi.org/10.1016/j.iot.2020.100170

6. Chu, Y.I. \& Wang, C.M. \& Park, Jeong Cheol \& Lader, P.F.. (2020). Review of cage and containment tank designs for offshore fish farming. Aquaculture. 519.734928. 10.1016/j.aquaculture.2020.734928.

7. C, Osueke \& Tajudeen, Olayanju. (2018). Design and Construction of an Automatic Fish Feeder Machine. International Journal of Mechanical Engineering and Technology (IJMET) Volume 9, Issue 10, October 2018, pp. 1631-1645 Thu Ya Kyaw, Andrew Keong Ng, (2017). Smart Aquaponics System for Urban Farming doi.org/10.1016/j.egypro.2017.12.694

8. Sicari, S., Cappiello, C., De Pellegrini, F. et al. A security-and quality-aware system architecture for Internet of Things. Inf Syst Front 18, 665-677 (2016). https://doi.org/10.1007/s10796-014-9538-x

9. Prajoona Valsalan, Tariq Ahmed Barham Baomar, Ali Hussain Omar Baabood. (2020). IoT Based Health Monitoring System. Journal of $\begin{array}{llll}\text { Critical Reviews, } 7 \text { (4), 739-743. } & \end{array}$ doi:10.31838/jcr.07.04.137

10. Boyd, C. E. (2017). General relationship between water quality and aquaculture performance in Ponds. In Fish diseases (pp. 147-166). Academic Press.

11. B, Klarin et al. (2019). New and smart approach to aeroponic and seafood production doi.org/10.1016/j.jclepro.2019.117665

12.Parra, L., Sendra S., Garcia, L., Lloret, J. (2018). Design and deployment of low-cost sensors for monitoring the water quality and fish behavior in aquaculture tanks during the feeding process. Sensors, 18(3), 750. https://doi.org/10.3390/s18030750

13. Juan, Huan, Hui Li, Fan Wu, Weijian Cao. (2020). Design of water quality monitoring system for aquaculture ponds based on NB-IoT. doi.org/10.1016/j.aquaeng.2020.102088

14. Hendri, H., S Enggari, Mardison, M R Putra, \& L N Rani (2019). Automatic System to Fish Feeder and Water Turbidity Detector Using Arduino Mega. In Journal of Physics: Conference Series (Vol. 1339, No. 1, p. 012013). IOP Publishing.

15. Estdale J., Georgiadou E. (2018). Applying the ISO/IEC 25010 Quality Models to Software Product. In: Larrucea X., Santamaria I., O'Connor R., Messnarz R. (eds) Systems, Software and Services Process Improvement. 
Audelon R. Benito, International Journal of Advanced Trends in Computer Science and Engineering, 9(1.3), 2020, 215 - 221

16. EuroSPI 2018. Communications in Computer and Information Science, vol 896. Springer, Cham.

17. Arispe, Maria. (2020). Integrating Spatial Data Analysis for Road Traffic Incident Response System.

https://doi.org/10.30534/ijatcse/2020/3291.22020

18. International Journal of Advanced Trends in Computer Science and Engineering. 9.218-223.10.30534/ijatcse/2020/3291.22020.

19. Ann Romalt, R. Mathusoothana S. Kumar (2020). An Analysis On Feature Selection Methods, Clustering And Classification Used In Heart Disease Prediction A Machine Learning Approach. Journal of Critical Reviews, 7 (6), 138-142. doi:10.31838/jcr.07.06.27
20.P. Prabhu, P. Valarmathie, K. Dinakaran (2020). To Forecast Learner Using Mining Classification To Evaluate Tertiary

21. Education. Journal of Critical Reviews, 7 (4), 329-330. doi:10.31838/jcr.07.04.61

22. Mata, Khatalyn E., Vinluan, Albert A., \& Gonzales, Dennis B. (2020). Intelligent Agent Using Artificial Neural Network for E-Service of Bureau of Fire Protection. International Journal of Advanced Trends in Computer Science and Engineering.

9. 58-62. 10.30534/ijatcse/2020/1091.22020

23.Telen, Mary. (2020). Blimp Stabilization Controller Optimization using Fuzzy Logic. International Journal of Advanced Trends in Computer Science and Engineering. 9. 76-83. 10.30534/ijatcse/2020/1391.220 